\title{
Policy Effects for Forest Conservation and Local Livelihood Improvements in Vietnam: A Case Study of Bach Ma National Park
}

Received: 20 July 2019

Accepted: 22 August 2019

Published: 29 August 2019

Publishing services provided by Knowledge E

(c). This article is distributed under the terms of the

Commons Attribution License,

which permits unrestricted use and redistribution provided that the original author and source are credited.

Selection and Peer-review unde the responsibility of the ICTSD 2018 Conference Committee.

\section{Abstract}

In 2012, the Vietnamese Government enacted "Decision 24" aiming at forest conservation and local development, incorporating the community support program in national park buffer zone to enhance the poor household livelihoods on the condition of reducing forest exploitation. In this program, the village submits an annual plan based on the needs of local people. To evaluate policy impacts, 1) provision of alternative job opportunity, 2) targeting the poor households, and 3) reducing frequency of incursion into national park, were examined. An interview was conducted on 95 households in the buffer zone of Bach Ma National Park. The achievements of the program depended on the village governance. There is a case of inappropriate policy selection that non-incursion $\mathrm{HH}$ s were selected and got benefits. It is important that the authority pays attention to not only the local people's demands but also their management abilities, production conditions, and access to technical support.

Keywords: Vietnam, national park, Bach Ma National Park, forest conservation, local livelihood, Decision 24, decision making

\section{Introduction}

In Vietnam, both natural and plantation forest areas are expanding. However, the quality of natural forests is still being degraded by local people's activities, such as illegal logging (Hoang et al. 2010). As the countermeasure for this situation, in 2012, the Vietnamese Government enacted "Decision 24", aiming for forest conservation and local development, featuring the community support program in national park buffer zones to improve the livelihood of the poor, on the condition of reducing forest exploitation (24/2012/QD-TTg). Total 5,500 billion VND were funded by the national government for 10 years covering whole Vietnam. National Park offices select target villages along with the criteria such as nearby the national park core zone, participating in illegal logging, less developed or poor, remote area, and ethnic minorities. It was not necessary to match all these conditions for each village. In a simple term, the villages that are economically dependent on the forest resources were selected. The selected communities propose 
an annual development plan, then, 40 million VND/year is granted on its approval by the District government. The local people can reflect their opinions and demands in the form of the annual development plan, namely they have opportunities to participate in decision making process.

If the activities are successfully implemented along the line with annual development plans made by the local people, it is supposed that local people play a major role, keep to the rule "do not enter the national park" and get the benefits of "economic assistance" in the form of a subsidies. For evaluating this program, it is necessary to examine the followings: 1) provision of alternative job opportunity and income generation, 2) targeting the poor households for effective poverty reduction, and 3) reducing frequency of incursion into national park, as policy for forest conservation. Based on the findings of examining these three aspects, we discuss the relevance and limitation of decision making by the local people in national park management.

\section{Literature Review}

National park plays an important role regarding conservation and the protection especially in tropical forests. For management of national park, it is necessary to discuss not only how to conserve, but also to conserve for whom. Various stakeholders play their own unique roles, and at the same time, appropriate benefits that are suited for each role should be given.

Relationship between the enforced power of management authority and the rights of land utilization of the local people at national park in Indonesia were categorized in 3 types (Takahashi, 2017); strict management disturbs local livelihoods (type 1), "paper park" where local people continue to utilize resources freely (type 2), and management authority and local people implement management along with collaborating conservation rules (type 3). It is concluded that type 3 is most effective because it applyies active conservation and less illegal activity. Tojo (2010) introduced the case of conflict between the government and the local people, caused by constructing barriers for national park management in Bangladesh. Thoughtless application of American nature reserve system disrespecting local traditions and lifestyles to Asia may cause mismanagement of natural resources. In the case of national park in Java, Indonesia, local people express negative opinions regarding the processes of national park establishments, constraints of resources and land utilization, and a poor economic status of the local people (Harada, 2011). 
Local people do not get the benefits and are disturbed in many cases. Due to this, local people usually do not have incentive to conserve natural resources. In addition they were normally isolated from decision making process in national park management,while the government and national park authority did decision making from top-down with little concern for local people (Table 1). In this situation, if local people could have taken part in the decision making, what will happen?

TABLE 1: Role, benefit, and decision making in national park management by stakeholders.

\begin{tabular}{|c|c|c|c|c|}
\hline \multicolumn{2}{|l|}{ Stakeholder } & Role & Benefit & Decision making \\
\hline \multicolumn{2}{|l|}{ Government } & Enforcement & $\begin{array}{l}\text { Finishing } \\
\text { enforcement }\end{array}$ & Yes \\
\hline \multicolumn{2}{|c|}{ National park authority } & $\begin{array}{l}\text { Management (ex. } \\
\text { patrol) }\end{array}$ & $\begin{array}{l}\text { Achieving } \\
\text { conservation }\end{array}$ & Yes \\
\hline \multirow[t]{2}{*}{ Local people } & $\begin{array}{l}\text { Using wood } \\
\text { products in national } \\
\text { park }\end{array}$ & Stop using & $?$ & No \\
\hline & Not using & Nothing & Nothing & No \\
\hline
\end{tabular}

\section{Methods}

\subsection{Study site}

Bach Ma National Park (hereafter BMNP) was established in 1991, and the area is 37,487ha (core zone: 12,064ha, ecological zone: 20,246ha, administrative zone: $5,188 \mathrm{ha})$. The buffer zone (57,482 ha) surrounds BMNP and is located in Nam Dong and Phu Loc Districts of Thua Thien Hue Province and Dong Giang District of Quang Nam Province. Approximately 79,000 people live inside the buffer zone.

BMNP is selected as a study site, because it is an important biodiversity hotspot hosting northern and southern flora and fauna species. In addition, an area of expansion $(+15,000$ ha in 2008$)$ closer to human residence makes the park more sensitive to human impact.

\subsection{Research methods}

The exploratory surveys were carried out on BMNP Office, Nam Dong District and other concerned institutes in Thua Thien Hue Province in August 2015.

In 2015, 12 villages in the buffer zone got financial support of Decision 24. For the interview survey, we selected three villages that utilized the program budget for 
agricultural development. Previously in the selected villagers, the poor had been entering forests for logging and NTFPs to secure their income. A semi-structured interview survey was conducted on 95 households (Table 2). The major survey contents were household characteristics, received policy supports, and changes in frequency of the park incursion. The surveys were conducted in August and December 2016 and October 2017.

TABLE 2: Number of sample HHs in each village.

\begin{tabular}{|l|c|c|c|}
\hline Village & \multicolumn{2}{|c|}{ Sample HHs } & $\begin{array}{c}\text { Total HHsof } \\
\text { villages }\end{array}$ \\
\hline & $\begin{array}{c}\text { Subsidized HHs } \\
\text { (All) }\end{array}$ & $\begin{array}{c}\text { Non-subsidized } \\
\text { HHs (random } \\
\text { sampling from } \\
\text { each village) }\end{array}$ & \\
\hline T & 23 & 15 & 213 \\
\hline X & 15 & 15 & 83 \\
\hline P & 12 & 15 & 82 \\
\hline Total & 50 & 45 & 378 \\
\hline
\end{tabular}

\section{Results and Discussions}

\subsection{Decision24 in Bach Ma National Park}

"Decision 24" in BMNP starting from 2013. In 2013, 10 villages in Nam Dong District got financial support of Decision 24, 9 villages in 2014, 12 villages in 2015, 4 villages in 2016 , and 8 villages in 2017. The major criteria of village selection were as follows. The village is locatednear to BMNP core zone, the villagers have been commonly engaging in illegal logging, it is less developed or economically poor, it is located in remote area, and ethnic minority lives there (from the interview of BMNP offices). However, not all the selected villages met all these conditions.

Even before Decision 24, BMNP office already formulated the rule which prohibits entering the national park for logging and NTFP collection,though many poor people still continued to enter the park for their livelihoods. For those villages worrying about illegal loggers and NTFP collectors, the financial supports of Decision 24 provided good incentive to apply the program. For getting support, villagers have to stop any activities causing forest exploitation inside the national park. After giving support, BMNP office checks the way of using the subsidies as planned and whether the local people stop entrance to the core zone. For getting support continuously, villagers have to stop activities causing forest exploitation inside national park and to pass an annual 
inspection. If not passing the inspection, the village cannot receive the supports and is to be replaced by other candidate village. The major inspection items are stop entering core zone and utilize budget as planned.

As the poor villagers used to invade into the park collecting various forest resources for their livelihoods, "Decision 24" aims to protect the forest by providing alternative income opportunities for them. Subsidized $\mathrm{HHs}$ of the program were selected from applicants by the two criteria of poverty level and economic dependence on the park.

\subsection{Provision of alternative job opportunity and income genera- tion}

Subsidized provisions are different among the villages. T village provided seedlings of durian or poultry chicks. $X$ and $P$ villages provided poultry chicks or piglets. In $T$ and $X$ villages, the HHs could not chose the kinds of subsidy (Table 3). In P village, each HHs rented 1.5 million VND and could buy what they need. The HHs that received this 1.5 million VND had to repay it.

TABLE 3: Provision of income generation in each village by the type of subsidies.

\begin{tabular}{l|c|c}
\hline Subsidy & Village & $\begin{array}{c}\text { Income } \\
\text { generation effect }\end{array}$ \\
\hline Durian seedlings & T & - \\
\hline Poultry chicks & X \& T & - \\
& P & + \\
\hline Piglets & X \& P & + \\
\hline
\end{tabular}

Regarding durian seedlings, in addition to enough land for planting, implementing fertilizing and other management costs are necessary to grow. Moreover, it takes approximately seven years until the fruit harvests. During this long pre-harvest period, growers must bear the costs without any income from durian trees. In two years (December 2016) or three years (October 2017) after receiving durian seedlings in $T$ village, the poor $\mathrm{HHs}$ had cash flow problems to take care of these seedlings, resulting in abandoning them.

In the case of poultry chicks, though no-income period (some months) is shorter than that of durian, proper feeding, growth environment management and veterinarian service are crucial for animal health. In reality, after 2 or 3 years in X and T villages many chicks were dead due to poor hygiene. Even growing well, income from chicken sale were merely temporal, because they could not reproduce chickens. On the one hand 
in $\mathrm{P}$ village, there were some cases where farmers earned enough income to purchase new chicks, then continued feeding.

Proper health care and veterinary service are also important for pig raising. In 2 or 3 years after in $X$ and $P$ villages, there were no case of piglet death and many farmers successfully continued feeding. And also, there was a case of buying other livestock after pig sale. In these villages, villagers had long experiences of pig raising and there was easy access to veterinary services.

\subsection{Targeting the poor households}

The rate of incursion into the park were $86 \%$ in participatory $\mathrm{HHs}$ and $67 \%$ in nonparticipatory HHs before implementing "Decision 24," therefore the selection of $\mathrm{HHs}$ in the villages could be judged as appropriate (Table 4). However, $7 \mathrm{HHs}$ received subsidies (durian seedlings: $3 \mathrm{HHs}$, poultry chicks: $4 \mathrm{HHs}$ ), even though they never encroached in the park. This situation that non-incursion HHs received subsidies was observed especially in T village.

TABLE 4: Number and rate of incursion and stop incursion HHs in each village.

Items
Number of HHs
Incursion $\mathrm{HHs}$ (\% in sample
$\mathrm{HHs}$ )
Stop incursion $\mathrm{HHs}$ (\% in
incursion $\mathrm{HHs}$ )

\begin{tabular}{|c|c|c|c|}
\hline \multicolumn{3}{|c|}{ X } & \multicolumn{2}{c|}{$T$} \\
\hline $\mathrm{S}$ & $\mathrm{N}$ & $\mathrm{S}$ & $\mathrm{N}$ \\
\hline 15 & 15 & 23 & 15 \\
\hline $14(93)$ & $12(80)$ & $18(78)$ & $9(60)$ \\
\hline $12(86)$ & $8(67)$ & $14(78)$ & $9(100)$ \\
\hline
\end{tabular}

\begin{tabular}{|c|c|}
\hline \multicolumn{2}{|c|}{$P$} \\
\hline$S$ & $N$ \\
\hline 12 & 15 \\
\hline $11(92)$ & $9(60)$ \\
\hline $9(82)$ & $9(100)$ \\
\hline
\end{tabular}

\begin{tabular}{|c|c|}
\hline \multicolumn{2}{|c|}{ Total } \\
\hline $\mathrm{S}$ & $\mathrm{N}$ \\
\hline 50 & 45 \\
\hline $43(86)$ & $30(67)$ \\
\hline $35(81)$ & $26(87)$ \\
\hline
\end{tabular}

While the seedlings were given to both the poor and relatively wealthier HHs who own enough lands. The wealthier $\mathrm{HH}$ tended to manage appropriately and grow seedlings well. However, the intended policy purposes of forest protection and poverty alleviation were not achieved, because the poor $\mathrm{HHs}$ could not manage the seedlings well. Similarly, the three non-poor HHs received poultry chicks, because these HHs had enough management techniques and experience, and were expected to spread the techniques to the poor.

In $\mathrm{P}$ village, subsidized $\mathrm{HH}$ s had to repay, therefore a part of poor $\mathrm{HHs}$ hesitated to receive subsidy to avoid defaults. As a result, low priority non-poor $\mathrm{HH}$ were selected. 


\subsection{Reducing frequency of incursion into national park}

The rate of stopping incursion of subsidized HHs (81\%) was slightly smaller than that of non-subsidized (87\%), therefore the effect of the policy was questionable (Table 4). In $\mathrm{X}$ village, the rate of subsidized $\mathrm{HHs}(86 \%)$ was significantly larger than that of nonsubsidized (67\%), therefore it seems that the policy was effective. However, in $T$ and $P$ villages, the rate of stopping incursion of non-subsidized $\mathrm{HHs}$ were notably higher than subsidized $\mathrm{HHs}$, therefore the major factors inhibiting incursion were not the policy itself.

"Alternative job opportunity" (Subsidized HHs: 37\%, Non-subsidized HHs: 47\%), then "Age / health" (27\%, 35\%), "Reducing forest resources" $(19 \%, 9 \%)$ are the reasons to stop incursion (Table 5). Only seven $\mathrm{HHs}$ in X village (16\% of subsidized $\mathrm{HH}$ in total) cited "Policy assistance" as a reason to stop incursion. However, they already had jobs such as acacia plantation labors, construction workers, or drivers other than livestock management. Therefore, it is difficult to say that the policy assistance itself was the main reason to stop incursion. Although, the government initiatives and efforts such as "Tightening regulations" and "Policy assistance" could promote them to look for alternative income earning opportunities other than forest incursion.

TABLE 5: Reasons for stop incursion in each village.

\begin{tabular}{|c|c|c|c|c|c|c|c|c|c|}
\hline \multirow[t]{2}{*}{ Items } & & \multicolumn{2}{|c|}{$x$} & \multicolumn{2}{|c|}{$\mathrm{T}$} & \multicolumn{2}{|c|}{$P$} & \multicolumn{2}{|c|}{ Total } \\
\hline & & $\mathrm{S}$ & $\mathrm{N}$ & $\mathrm{S}$ & $\mathrm{N}$ & $\mathrm{S}$ & $\mathrm{N}$ & $\mathrm{S}(\%)$ & $\mathrm{N}(\%)$ \\
\hline & Number of $\mathrm{HHs}$ & 15 & 15 & 23 & 15 & 12 & 15 & 50 & 45 \\
\hline \multirow{6}{*}{$\begin{array}{l}\text { Reasons } \\
\text { (multiple } \\
\text { answers) }\end{array}$} & $\begin{array}{l}\text { Alternative job } \\
\text { opportunity }\end{array}$ & - & 6 & 4 & 4 & 5 & 6 & $16(37)$ & $16(47)$ \\
\hline & Age / health & 1 & 4 & 8 & 7 & 3 & 2 & $12(27)$ & $12(35)$ \\
\hline & $\begin{array}{l}\text { Reducing forest } \\
\text { resources }\end{array}$ & 1 & 2 & 5 & 1 & 2 & 0 & $8(19)$ & $3(9)$ \\
\hline & $\begin{array}{l}\text { Policy } \\
\text { assistance }\end{array}$ & 7 & - & 0 & - & 0 & - & $7(16)$ & - \\
\hline & $\begin{array}{l}\text { Tightening } \\
\text { regulation }\end{array}$ & 0 & 1 & 1 & 1 & 1 & 1 & $2(5)$ & $3(9)$ \\
\hline & Total & 16 & 13 & 18 & 13 & 9 & 9 & 43 (100) & $34(100)$ \\
\hline
\end{tabular}

\subsection{Discussions}

Regarding provisions of alternative job and income generation opportunities, it seems to fail in T village due to the improper subsidy contents. In contrast, the subsidies 
of $\mathrm{P}$ village could have provided sustainable income source because subsidized HHs purchased needful goods such as poultry chicks and piglets with the fund.

Considering poverty reduction, selection of non-poor HHs did not meet policy objectives in T village. In the same way, in $\mathrm{P}$ village even some of eligible poor $\mathrm{HHs}$ declined receiving subsidies, due to necessity of repayment.

Examining the policy impact on reducing frequency of incursion into national park, low priority $\mathrm{HH}$ s that already stopped incursion into the park were selected in $\mathrm{T}$ and $\mathrm{P}$ villages, therefore direct policy effect was questionable. To stop incursion into the park and provision of alternative job opportunities, it is crucial to provide policy supports that meet $\mathrm{HHs}$ demands in the case of $\mathrm{P}$ village and proper $\mathrm{HH}$ targeting in the case of $\mathrm{X}$ village.

\section{Conclusion}

To clarify the effects of forest conservation policy in which local people participated in decision making process, the interview survey was conducted in a Vietnamese national park.

Even though decision making was done at the village level by majority vote of the villagers, subsidy did not necessary match the demands of target HHs. Therefore, it is crucial to carefully examine the real needs and their management abilities of the target population to fully utilize subsidies. As the villages were given high local autonomy of planning and operation, their governance appeared as a critical factor in success or failure of the implementation of conservation policy. There is a case of inappropriate policy selection that non-incursion $\mathrm{HHs}$ were selected and got benefits, and the aims of the policy were not achieved. It is important that the authority pays close attention to not only the local people's demands but also their management abilities, production environments, access to technical support such as veterinary service and market condition. Therefore, to achieve the purpose of conservation and good management of the park, an active involvement in decision making process of the authority is indispensable together with understanding and cooperation of local people.

\section{Acknowledgement}

The study was supported by JSPS KAKENHI Grant Number 15H05122 (Representative: HARADA Kazuhiro). Ms. Nguyen Thi Tam, Institute of Resources and Environment in Hue University, was generous in support when we conducted our research. 


\section{References}

[1] Harada K. 2011. "Conflict management to tropical forests: Beyond the dichotomy of protection and conservation." Genjinsya, Tokyo. 260 p. (in Japanese language)

[2] Hoang MH, Do TH, van Noordwijk M, Pham TT, Palm M, To XP, Doan D, Nguyen TX, Hoang TVA. 2010. "An Assessment of opportunities for reducing emissions from all land uses: Vietnam preparing for REDD." Final National Report. ASB Partnership for the Tropical Forest Margins. Nairobi, Kenya. 85 p.

[3] Takahashi S. 2017. "Rivalry over national park" Okuda T. (eds.) "Can efforts against global warming save tropical forests?" Bunitsusougousyuppan, Tokyo. 71-95 pp. (in Japanese language)

[4] Tojo B. 2010. "Conflict between forest management system and local people in Madhupur National Park, Bangladesh.” Ichikawa M., Ubukata F., Naito D. (eds.) "People and forest management in tropical Asia: Local-level impacts of diverse governance systems." Jinbunsyoin, Kyoto. 45-66 pp. (in Japanese language) 